\title{
Geopolymers Using Rice Husk Silica and Metakaolin Derivatives; Preparation and Their Characteristics
}

\author{
Francisco J. López ${ }^{1,2}$, Satoshi Sugita ${ }^{2}$, Motohiro Tagaya1, Takaomi Kobayashi' \\ ${ }^{1}$ Department of Materials Science and Technology, Nagaoka University of Technology, Nagaoka, Japan \\ ${ }^{2}$ Departament of Chemestry, Universidad de Guanajuato, Guanajuato, Mexico \\ Email: takaomi@nagaokaut.ac.jp
}

Received 2 April 2014; revised 1 May 2014; accepted 20 May 2014

Copyright (C) 2014 by authors and Scientific Research Publishing Inc.

This work is licensed under the Creative Commons Attribution International License (CC BY).

http://creativecommons.org/licenses/by/4.0/

c) (i) Open Access

\begin{abstract}
The effect of the amorphous silica derived from biomass rice husk (RH) in the alkaline activating solution on the properties was investigated in geopolymerization process, when metakaolin was used as the aluminum source from metakaolin (MK). With changing a molar ratio of $\mathrm{SiO}_{2} / \mathrm{Al}_{2} \mathrm{O}_{3}=$ 3.0 and 10, the curing in the preparation of geopolymers was carried out at $85^{\circ} \mathrm{C}, 100^{\circ} \mathrm{C}$ and $200^{\circ} \mathrm{C}$. Viscoelastic properties of the geopolymer pastes including $\mathrm{SiO}_{2}$ and $\mathrm{Al}_{2} \mathrm{O}_{3}$ components suggested that the alkaline activation was found in higher RH silica source. The mineralogical and microstructural characteristics of the cured products were evaluated to be amorphous aluminosilicate.
\end{abstract}

\section{Keywords}

Rice Husk, Silica, Metakaolin, Geopolymer

\section{Introduction}

Geopolymerization is an effective manner to process and reuse silicates, aluminates or aluminosilicates in mineral waste. It is known that geopolymers are alkaline activated aluminosilicates consisting of reactive species of $\mathrm{SiO}_{2}$ and $\mathrm{Al}_{2} \mathrm{O}_{3}$ to produce high-strength materials that can effectively immobilize other industrial by-products, and even hazardous waste. Generally, the formula of the geopolymers is $\mathrm{M}_{n}\left(-\left(\mathrm{Si}-\mathrm{O}_{2}\right)_{\mathrm{z}}-\mathrm{Al}-\mathrm{O}\right)_{n} \cdot \mathrm{wH}_{2} \mathrm{O}$, where $\mathrm{M}$ is an alkaline cation ( $\mathrm{Na}, \mathrm{K}$ or $\mathrm{Ca}$ ), $\mathrm{z}$ is generally assigned a value of 1,2 or 3 and $\mathrm{n}$ is the degree of polymerization [1]. Geopolymers are interesting materials formed by polycondensation of the silicon and aluminum species resulting from the dissolution of their raw materials found in fly ash, slag, metakaolin in alkaline solution condition [2]. Usually, the geopolycondenzation depends of $\mathrm{SiO}_{2} / \mathrm{Al}_{2} \mathrm{O}_{3}$ ratio and alkali concentration [3] [4]. Geopo- 
lymerization is affected by the reactive precursor, meaning that $\mathrm{OH}$-concentration and curing conditions finally produce three-dimensional networks that comprise geopolymer matrices at different time and temperature [5].

Therefore, the advantage is the proven durability and erosion resistance of both ancient mortars and cements and modern geopolymer cements. It was known that a great number of minerals-industrial wastes were studied as raw materials for geopolymer synthesis, including pozzolana [6], natural aluminosilicate minerals, metakaolin, fly ash, granulated blast furnace slag, fly ash and kaolinite mixture, red mud and metakaolin mixture [3] [7]-[12].

More importantly, the starting raw materials play a significant role in the geopolymer reaction and affect the mechanical properties and microstructure of the final geopolymericproducts [3] [11] [13]. It would be expected that silica from of rice husk (RH) is an excellent pozzolanic material, but that has not been extensively studied in geopolymerization. RH silica can be generate by the combustion process of RH [14], itself is biomass and to be an issue for sustainability environment, due to its abundant amount and capability to resist natural degradation. $\mathrm{RH}$ silica therefore is an alternative material with good pozzolanic reactivity, to be included in the geopolymer mixture to complete the ratio of modulus of $\mathrm{SiO}_{2} / \mathrm{Al}_{2} \mathrm{O}_{3}$. In the present study, the effect of the RH silica was determined on the resultant geopolymers as a function of curing time and temperature. It was investigated that the rheometry properties of the geopolymer pastes and properties of resultant geopolymers were compared at different $\mathrm{SiO}_{2} / \mathrm{Al}_{2} \mathrm{O}_{3}$ ratios at different cure temperature in addition with their bulk characteristics. Since such biomass resource was attractively interesting in point of view of sustainability, this paper focused on the detail in the geopolymerization.

\section{Experimental}

\subsection{Materials}

Silica was obtained from by leaching of rice husk in dilute HCI $(5 \mathrm{M})$ and burned at $700^{\circ} \mathrm{C}$ to produce pure amorphous white silica. The chemical composition of obtained silica was determined by XRF reveals at $99.5 \%$ of $\mathrm{SiO}_{2}$ with a surface area calculated from BET method of $207.5 \mathrm{~m}^{2} / \mathrm{g}$. Obtaining Metakaolin was carry out by dehydroxylation of kaolinite at $750^{\circ} \mathrm{C}$ by $20 \mathrm{~h}$ according to reference [15] [16]. The chemical composition of metakaolin was measured by XRF for $52 \%$ of $\mathrm{SiO}_{2}$ and $42.1 \%$ of $\mathrm{Al}_{2} \mathrm{O}_{3}$. The surface area of metakaolin calculated from BET method was $11.5 \mathrm{~m}^{2} / \mathrm{g}$.

\subsection{Preparation of Geopolymer}

Geopolymers were prepared by changing a molar ratio of $\mathrm{SiO}_{2} / \mathrm{Al}_{2} \mathrm{O}_{3}=3.0$ and 10 for GP-3 and GP-10, respectively. For $\mathrm{NaOH}$ and $\mathrm{Na}_{2} \mathrm{SiO}_{3}$ molar ratio, $\mathrm{Na}_{2} \mathrm{O} / \mathrm{SiO}_{2}=0.25$ was used. The preparation procedure is as followed as described in Figure 1. The powders of RH silica were mixed with $\mathrm{NaOH}$ solution until dissolution. Then, metakaolin (MK) powders were added and mixed together for $15 \mathrm{~min}$ in the silica solution. The paste samples were cast in plastic molds with a diameter of $20 \mathrm{~mm}$ and height of $40 \mathrm{~mm}$. The curing time for preparation of geopolymers was carried out at $85^{\circ} \mathrm{C}, 100^{\circ} \mathrm{C}$ and $200^{\circ} \mathrm{C}$ in a conventional oven at open mold(). Before the curing process, rheological measurements of the paste samples were performed using a controlled stress rheometer (Anton PaarPhysica MCR 301 Rheometer), as operated in controlled strain mode. The geopolymer paste was prepared manually outside the rheometer and then introduced into the rheometer disk after mixing. Transferring the geopolymer to the measurement cell generates residual stresses, when the sample was prior to

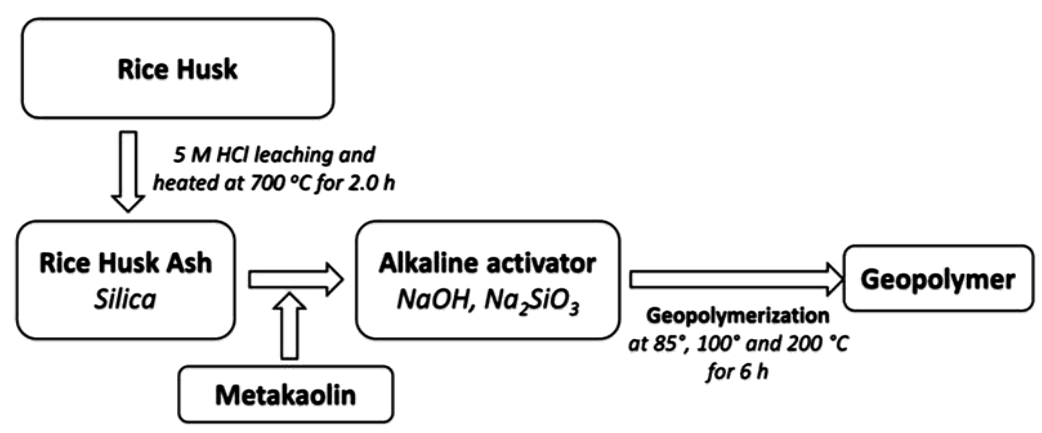

Figure 1. Protocol of geopolimerization synthesis. 
each rheological measurement. This was done before each test by applying a strain at frequency of $1 \mathrm{~Hz}$. Characterization of the geopolymers was obtained by infrared spectroscopy (FT-IR), X-ray diffraction (XRD) and scanning electron microscope (SEM).

\section{Results and Discussion}

Figure 1 presents synthesis protocol of RH silica-MK geopolymerization. In this process, the RH silica and MK were produced by sintered rice husk and kaolin at $700^{\circ} \mathrm{C}$ and $750^{\circ} \mathrm{C}$, respectively, before the provided.

Figure 2 shows the strain sweep at a frequency of $1 \mathrm{~Hz}$ for raw material activated by $\mathrm{NaOH}$ and geopolymer paste with a satisfactory repeatability. It was observed in the viscous elastic rheometer that the deformation of the geopolymers pastes (a) was higher than that of RH silica and MK (b). It was understanding that the linear viscoelasticity region was due to nondestructive to the geopolymerization of the silica-alumina component in the

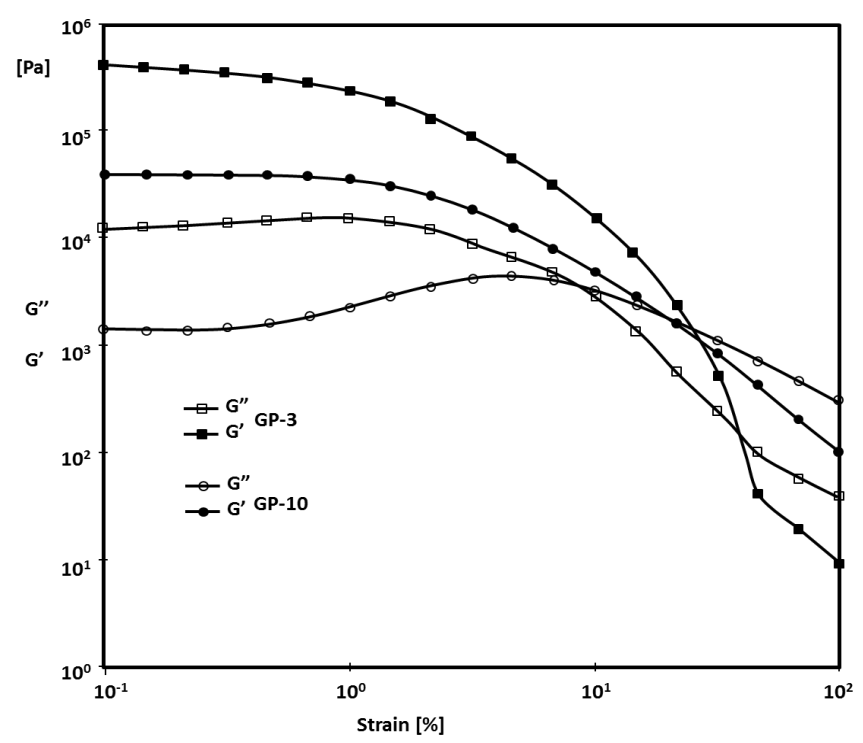

(a)

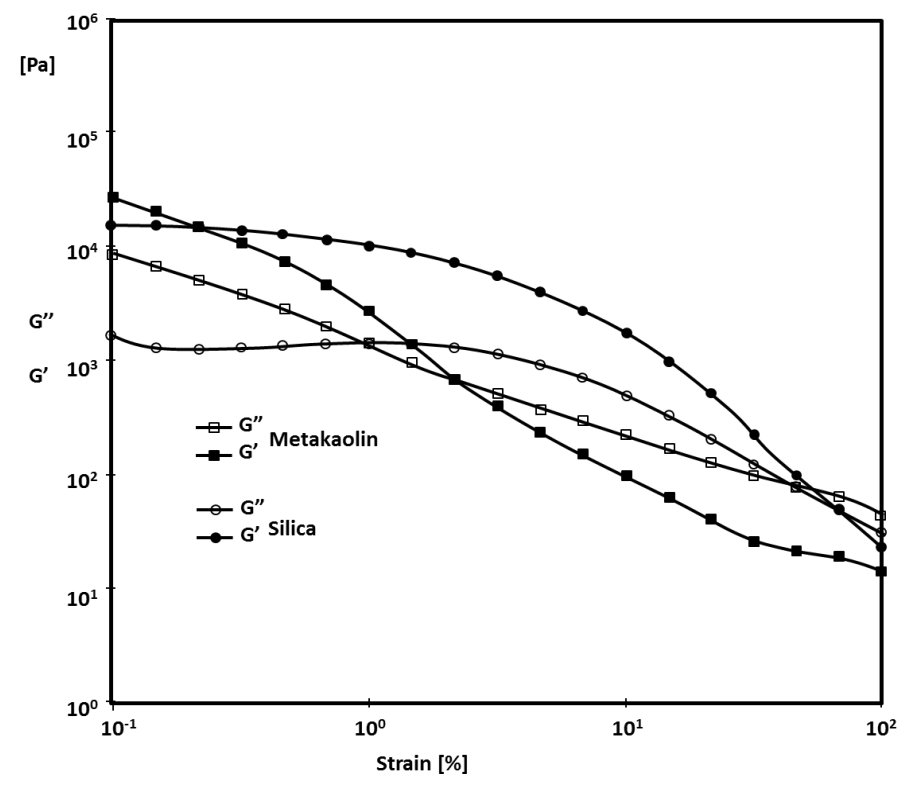

(b)

Figure. 2. Strain sweep test for (a) geopolymer paste of GP-3and GP-10 at $25^{\circ} \mathrm{C}$, and (b); silica from rice husk and metakaolin activated by $\mathrm{NaOH}$. 
activated paste, when a critical strain $\gamma_{C}$ was applied. Strain was generally taken as the strain value at the storage modulus equal to $90 \%$ of the plateau modulus. In both cases for GP-3 and GP-10, the elastic modulus (G') came to be higher than that of viscous modulus (G”). That meant that the paste was considered in the gelation for solid.

When comparison made between the paste of GP-3 and GP-10, high values of G' and G” for geopolymers pastes were observed, indicating that the geopolymerization in the activator condition was easily occur at the point of G”/G' = 1, GP-3 containing higher alumina and higher strain. This means that the high MK content was better for the polycondensation reaction.

Figure 3 show time curves of G' and G" at different temperature. It was also observed at fixed temperature of $60^{\circ} \mathrm{C}, 85^{\circ} \mathrm{C}$ and $100^{\circ} \mathrm{C}$ for GP-3 and GP-10. The both G' and G” were increased with increasing time and then
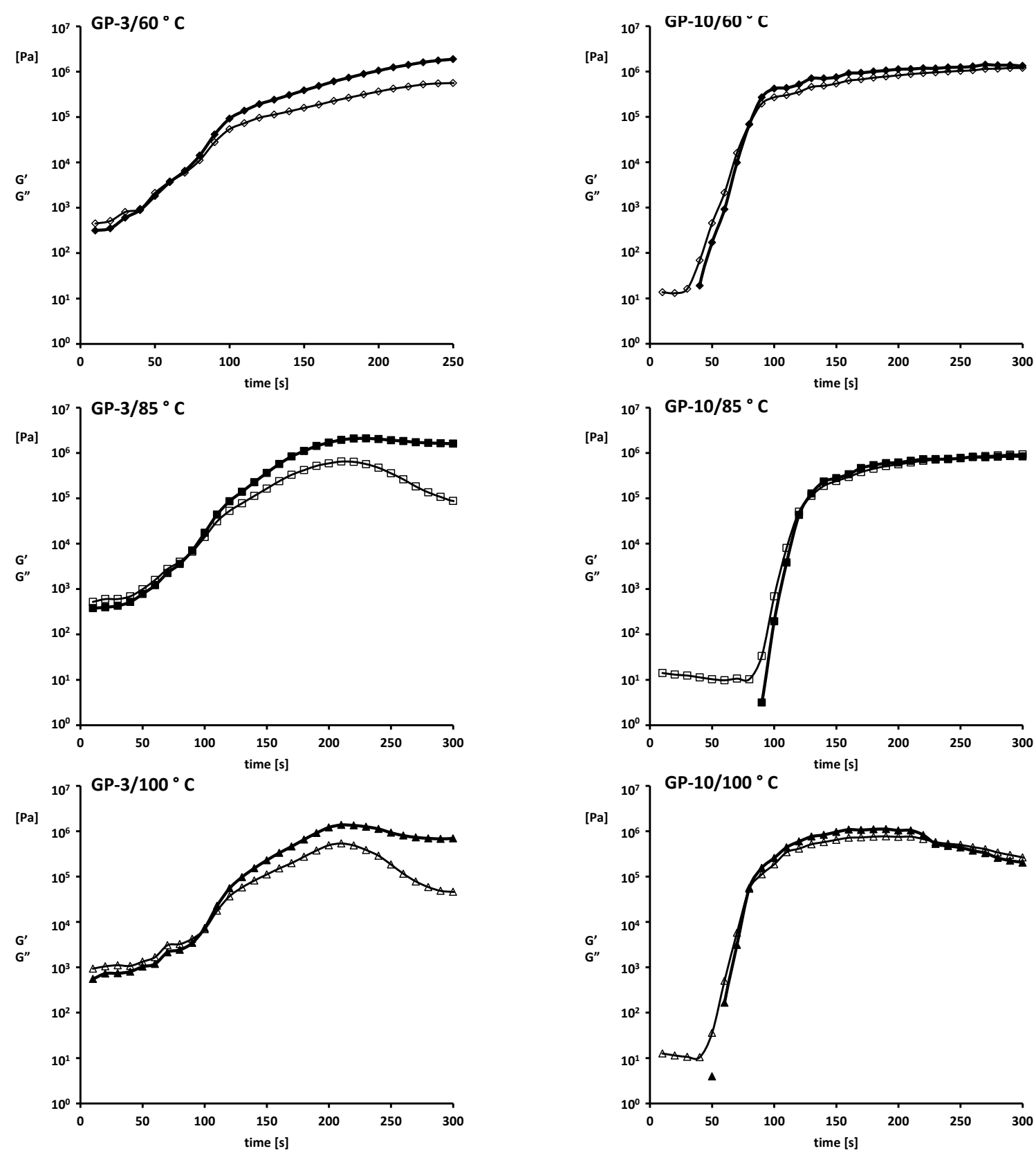

Figure 3. The G' and G" as a function of time and maintaining a constant temperature at $60^{\circ} \mathrm{C}, 85^{\circ} \mathrm{C}$ and $100^{\circ} \mathrm{C}$ for $\mathrm{GP}-3$ and GP-10 [ for elastic modulus (G’) and $\diamond$ for viscous modulus (G’’)]. 
became to be constant at about 250 seconds. The comparison between GP-3 and GP-10 meant that the cure ability of the activated paste was higher in GP-10. The time curves suggested that the curing was finished at about 2 min heating. But, the GP-3 increased the G' and G” values near 200-250 seconds and then was cured in the geopolymer solidified. Due to that the polycondensation reaction occurs, the geopolymer paste loses viscosity, while the paste became a solid material, the elastic modulus became constant at the longer time. This change was exatly observed after $250 \mathrm{~s}$ for GP-3 at $60^{\circ} \mathrm{C}$ and $210 \mathrm{~s}$ for GP-3 at $85^{\circ} \mathrm{C}$ and $100^{\circ} \mathrm{C}$. At a high amount of $\mathrm{Al}_{2} \mathrm{O}_{3}$ for GP-3, it was less to be on geopolymerization. However, the GP-10 registered a constant modulus G' and G” for all the cases due to with a high content of RH silica on the geopolymer pastes which made a very elastic and viscous material even after 250 s. Figure 4 shows viscosity of the pastes of GP-3 and GP-10 at different temperature. It was noticed that the viscoelasticity of the paste decreased, when the temperature was high. The resultant viscosity of the GP-10 was higher than that of GP-3, due to the increment of the $\mathrm{SiO}_{2}$ in geopolymer composition resulted in a decrease of the viscosity of the pastes. After polycondensation reaction for GP-3 and GP-10, the microstructures of geopolymers at different curing temperature were observed. Figure 5 shows

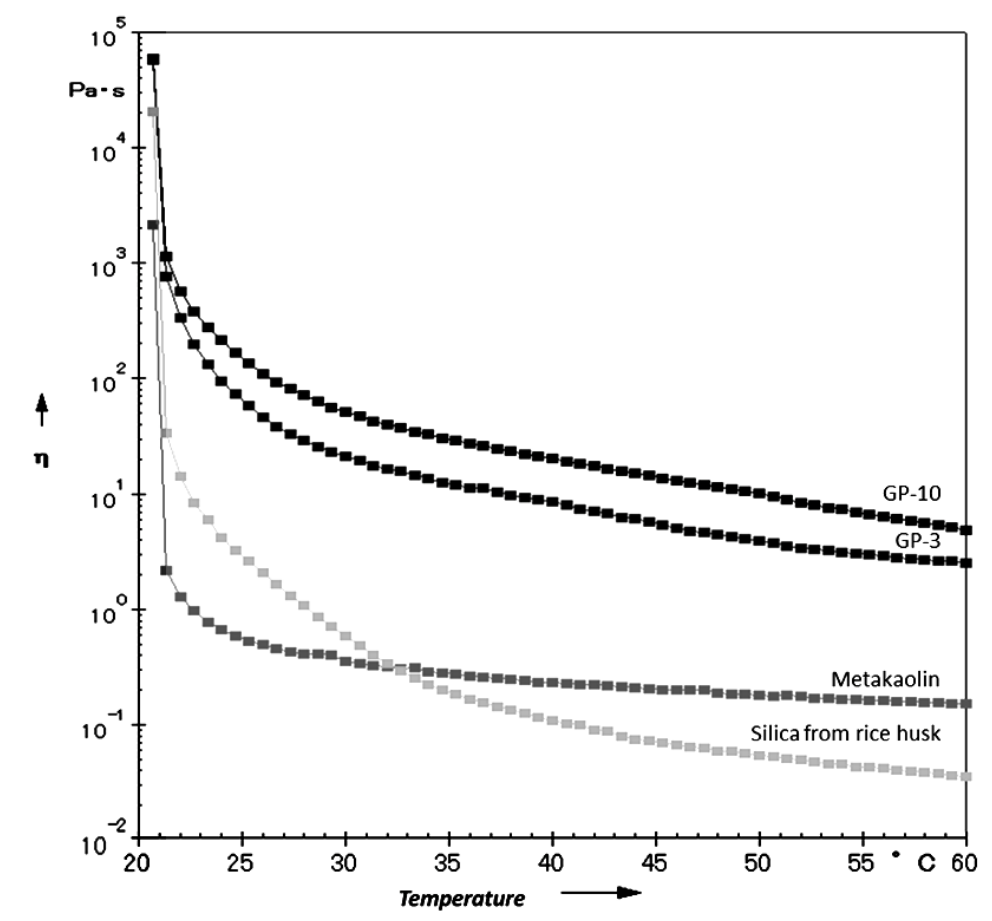

Figure 4. Viscosity test for silica from rice husk, metakaolin activated by $\mathrm{NaOH}$ and geopolymer pasteof GP-3 and GP-10 from $20^{\circ} \mathrm{C}$ to $60^{\circ} \mathrm{C}$.
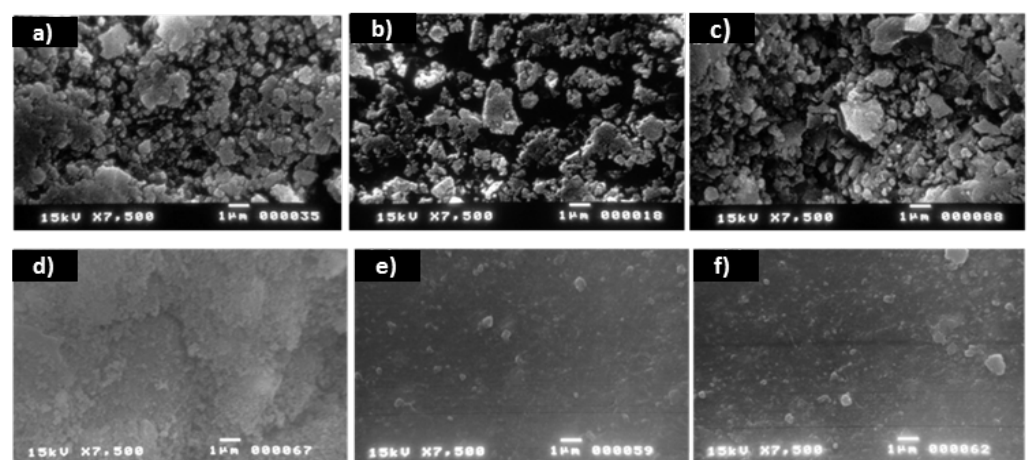

Figure 5. SEM imagines of (a) GP-3 at $85^{\circ} \mathrm{C}$; (b) GP-3 at $100^{\circ} \mathrm{C}$; (c) GP-3 at $200^{\circ} \mathrm{C}$; (d) GP-10 at $85^{\circ} \mathrm{C}$; (e) GP-10 at $100^{\circ} \mathrm{C}$ and (f) $\mathrm{GP}-10$ at $200^{\circ} \mathrm{C}$. 
microscope picture for the resultant geopolymers. The pictures showed the formation of the heterogeneous matrix after the polycondensation of raw material. It was seen that the geopolymers of the GP-3 became to be more porosity matrix. Their porosities of the geopolymers decreased at the GP-10 containing higher RH silica contents. It was seen that with the increment of the temperature, changing into a homogeneous phase was found in the geopolymer matrix, wich was condensed at $200^{\circ} \mathrm{C}$ of the geopolymer matrix.

The XRD patters of the geopolymers of GP-3 and GP-10 at different curing temperature are shown in Figure 6. It was seen that the peak shift toward higher $2 \theta$ side was significant in the cases of GP-3. This meant that the

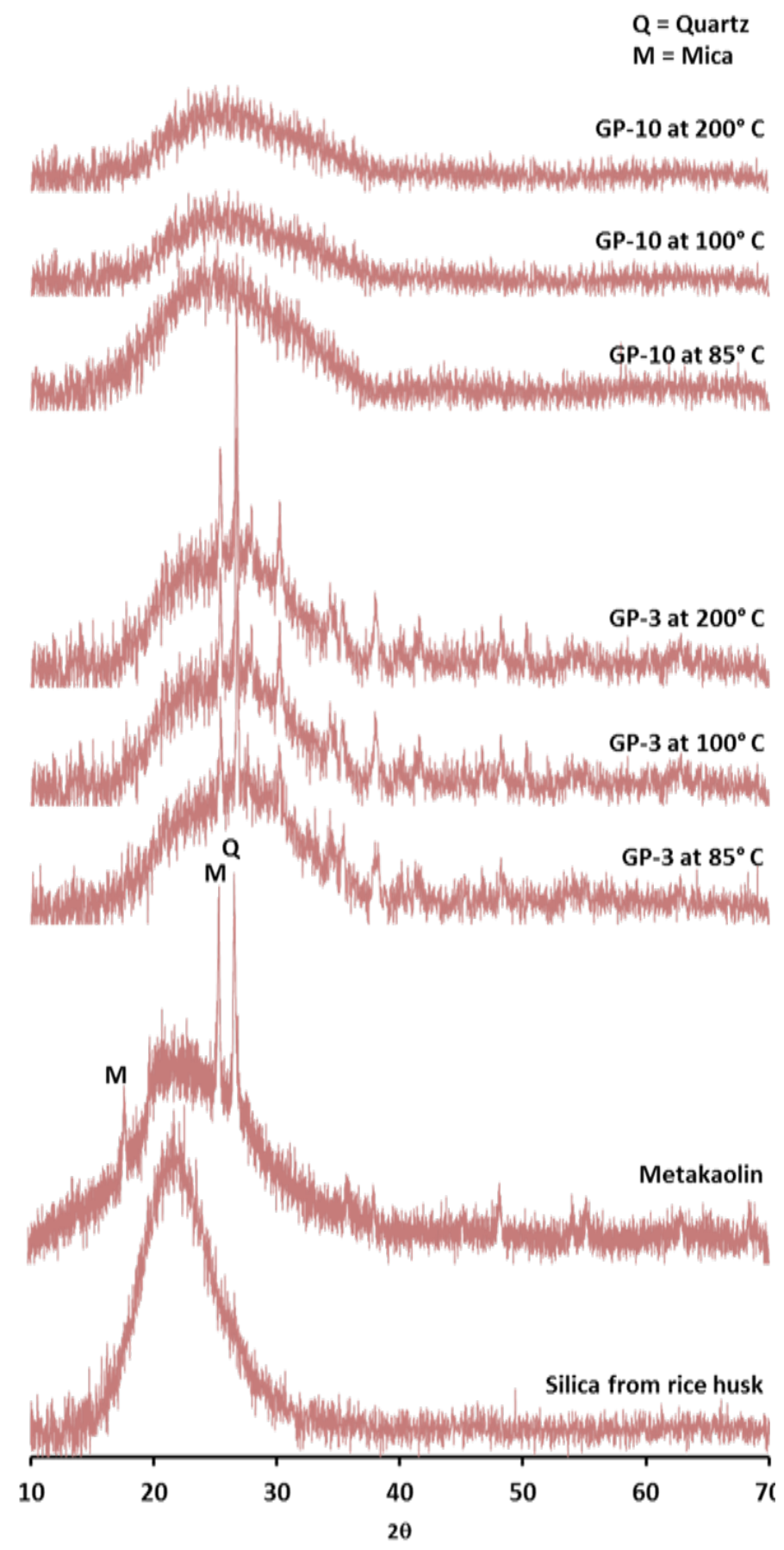

Figure 6. X-ray diffraction of geopolymers synthetized by alkali activation of silica from rice husk and metakaolin different curing time. 
reconstruction of silica-alumina order in the paste was highly observed at the polycondensed GP-3. This was strongly demonstrated geopolymerization with the amorphous nature of the samples. In addition with the XRD results, the alteration and restructuring of materials during geopolymerization were also suggested in the diffraction pattern by the marked shift in the scattering diffraction peak for each samples. When the starting materials were activated with an alkaline solution, the scattering diffraction peak shifted from $\sim 20^{\circ}$ to $\sim 25^{\circ}-28^{\circ}$ in $2 \theta$. This suggested that the local bonding environment was changed during the geopolymerization process [17]. Apparently, an increase of the temperature from $85^{\circ} \mathrm{C}$ to $200^{\circ} \mathrm{C}$, no influence of the amorphous structure of the geopolymers was observed.

The data suggested that the silica/alumina component was affected to the reconstruction. In order to confirm this from chemical reaction of RH silica and MK we measured FT-IR spectra of the resultant GP-3 and GP-10. Figure 7 shows the infrared spectra of the geopolymer matrixes. The band around $460 \mathrm{~cm}^{-1}$ was related to $\mathrm{Al}-\mathrm{O}$ and $\mathrm{Si}-\mathrm{O}$ in plane and bending modes, $730 \mathrm{~cm}^{-1}$ with octahedral $\mathrm{Al}$ and $820 \mathrm{~cm}^{-1}$ with tetrahedral $\mathrm{Al}-\mathrm{O}$ stretching and, the peak $1030 \mathrm{~cm}^{-1}$ was assigned with asymmetric Si-O-Al stretching [18] [19]. The change in the intensity of the IR peaks was associated with the structural reorganization by the geopolymerization of RH silica and MK. In the geopolymer samples prepared using the RH silica, there was an increase and broaden in the IR intensity of IR peaks indicating higher polymerization, when the content of the RH silica was high. The IR peak around $1030 \mathrm{~cm}^{-1}$ meant that overlapping of the IR peaks related to $\mathrm{SiQ}_{\mathrm{n}}(\mathrm{n}=0-4)$ structural units [20]-[24] was caused and became broaden, especially a higher temperature. In addition, the spectral data has broadening peak at $3400 \mathrm{~cm}^{-1}$ for $\mathrm{OH}$ stretching of $\mathrm{Si}-\mathrm{OH}$ and Al-OH. It was apparent that the GP-10 system contained broadening tendency on the $\mathrm{OH}$ stretching peak. This meant that higher RH silica content easily occurred in the geopolymerization with MK.

\section{Conclusion}

Based on the result of these analyses, it could be concluded that silica obtained from rice husk combustion at $700^{\circ} \mathrm{C}$ became to be raw material for geopolymers and significantly contributed to the formation of geopolymer

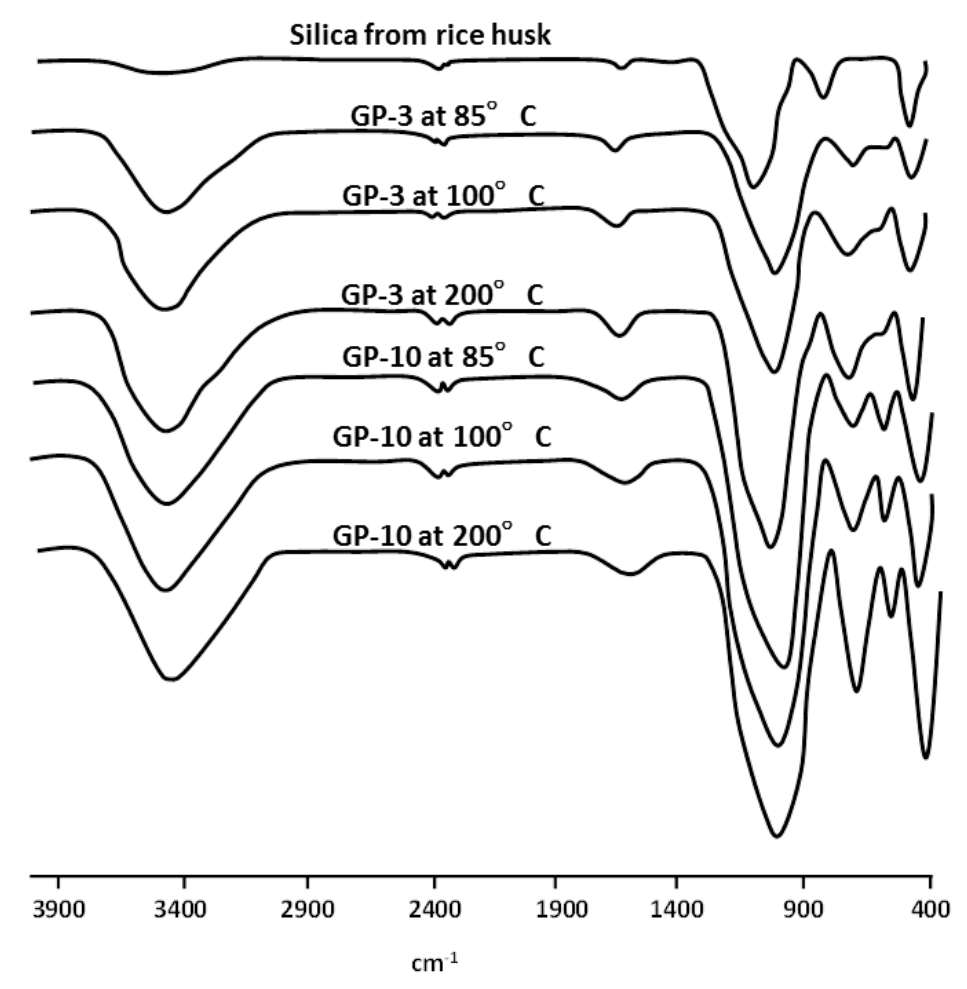

Figure 7. Infrared spectra of geopolymers synthetized by alkali activation of silica from rice husk and metakaolin at different curing time. 
matrix with MK. The presence of the RH silica was an important during the geopolymerization reaction due tosodium hydroxide activation. The evolution of the viscoelastic parameters of the geopolymers GP-3 and GP-10 were performed by dynamic rheology method for pastes. In general, the elastic modulus quickly exceeded the viscous modulus regardless of the geopolymer studied, indicating that both materials was on the process of solidified geopolimerization having reconstructed $\mathrm{Si}$ and $\mathrm{Al}$ species.

\section{References}

[1] Davidovits, J. (1988) Geopolymer Chemistry and Properties. Proceedings of the 1st International Conference on Geopolymer '88, Vol. 1, Compiegne, 1-3 June 1988, 25-48.

[2] Fernandez-Jimenez, A. and Palomo, A. (2005) Composition and Microstructure of Alkali Activated Fly Ash Binder: Effect of the Activator. Cement and Concrete Research, 35, 1984-1992. http://dx.doi.org/10.1016/j.cemconres.2005.03.003

[3] Hua, X. and Van Deventer, J.S.J. (2000) The Geopolymerisation of Alumino-Silicate Minerals. International Journal of Mineral Processing, 59, 247-266. http://dx.doi.org/10.1016/S0301-7516(99)00074-5

[4] Hua, X. and Van Deventer, J.S.J. (2002) Geopolymerisation of Multiple Minerals. Minerals Engineering, 15, 11311139. http://dx.doi.org/10.1016/S0892-6875(02)00255-8

[5] Rovnaník, P. (2010) Effect of Curing Temperature on the Development of Hard Structure of Metakaolin-Based Geopolymer. Construction and Building Materials, 24, 1176-1183. http://dx.doi.org/10.1016/j.conbuildmat.2009.12.023

[6] Allahverdi, A., Mehrpour, K. and Kani, E.N. (2008) Investigating the Possibility of Utilizing Pumice-Type Natural Pozzonal in Production of Geopolymer Cement. Ceramics-Silikaty, 52, 16-23.

[7] J. Davidovits (1991) Geopolymers: Inorganic Polymeric New Materials. Journal of Thermal Analysis, 37, $1633-1656$.

[8] Duxson, P., Fernandez-Jimenez, A., Provis, J.L., Lukey, G.C., Palomo, A. and Van Deventer, J.S.J. (2007) Geopolymer Technology: The Current State of the Art. Journal of Materials Science, 42, 2917-2933. http://dx.doi.org/10.1007/s10853-006-0637-z

[9] Latella, B.A., Perera, D.S., Durce, D., Mehrtens, E.G. and Davis, J. (2008) Mechanical Properties of Metakaolin-Based Geopolymers with Molar Ratios of Si/Al Approximate to 2 and Na/Al Approximate to 1. Journal of Materials Science, 43, 2693-2699. http://dx.doi.org/10.1007/s10853-007-2412-1

[10] He, J., Zhang, G., Hou, S. and Cai, C. (2001) Geopolymer-Based Smart Adhesives for Infrastructure Health Monitoring: Concept and Feasibility. Journal of Materials in Civil Engineering, 23, 100-109. http://dx.doi.org/10.1061/(ASCE)MT.1943-5533.0000140

[11] Van Jaarsveld, J.G.S., van Deventer, J.S.J. and Lukey, G.C. (2002) The Effect of Composition and Temperature on the Properties of Fly Ash- and Kaolinite-Based Geopolymers. Chemical Engineering Journal, 89, 63-73.

[12] Dimas, D.D., Giannopoulou, I.P. and Panias, D. (2009) Utilization of Alumina Red Mud for Synthesis of Inorganic Polymeric Materials. Mineral Processing and Extractive Metallurgy Review, 30, 211-239. http://dx.doi.org/10.1080/08827500802498199

[13] Ambroise, J., Maximilien, S. and Pear, J. (1994) Properties of Metakaolin Blended Cements. Advanced Cement Based Materials, 1, 161-168. http://dx.doi.org/10.1016/1065-7355(94)90007-8

[14] Chakraverty, A., Mishra, P. and Banerjee, H.D. (1988) Investigation of Combustion of Raw and Acid-Leached Rice Husk for Production of Pure Amorphous White Silica. Journal of Materials Science, 23, 21-24. http://dx.doi.org/10.1007/BF01174029

[15] Granizo, M.L. and Banco, M.T. (1998) Alkaline Activation of Metakaolin. Journal of Thermal Analysis, 52, $957-965$. http://dx.doi.org/10.1023/A:1010176321136

[16] Monzó, M., Fernández-Jiménez, A., Vicent, M., Palomo, A. and Barba, A. (2008) Activación Alcalina de Metacaolín. Efecto de la Adición de Silicato Soluble y de la Temperatura de Curado. Cerámica y Vidrio, 47, 35-43. http://dx.doi.org/10.3989/cyv.2008.v47.i1.210

[17] Delaira, S., Rud’Hommea, É, Peyratouta, C., Smitha, A., Michauda, P., Eloyb, L., Jousseinc, E. and Rossignola, S. (2012) Durability of Inorganic Foam in Solution: The Role of Alkali Elements in the Geopolymer Network. Corrosion Science, 59, 213-221. http://dx.doi.org/10.1016/j.corsci.2012.03.002

[18] Palomo, A. and Glasser, F.P. (1992) Chemically-Bonded Cementitiousn Material Based on Metakaolin. British Ceramic Transactions, 91,107-112.

[19] Phair, J.W., Van Deventer, J.S.J. and Smith, J.D. (2000) Mechanism of Polysialation in the Incorporation of Zirconia into Fly Ash Based Geopolymers. Industrial \& Engineering Chemistry Research, 39, 2925-2934. http://dx.doi.org/10.1021/ie990929w 
[20] Mollah, M.Y.A., Hess, T.R. and Cocke, D.L. (1994) Surface and Bulk Studies of Leached and Unleached Fly Ash Using XPS, SEM, EDS and FTIR Techniques. Cement and Concrete Research, 24, 109-118.

http://dx.doi.org/10.1016/0008-8846(94)90091-4

[21] Dimas, D., Giannopoulou, I. and Panias, D. (2009) Polymerization in Sodium Silicate Solutions: A Fundamental Process in Geopolymerization Technology. Journal of Materials Science, 44, 3719-3730. http://dx.doi.org/10.1007/s10853-009-3497-5

[22] Sitarz, M., Handke, M. and Mozgawa, W. (2000) Identification of Silicooxygen Rings in $\mathrm{SiO}_{2}$ Based on IR Spectra. Spectrochim. Spectrochimica Acta, Part A: Molecular and Biomolecular Spectroscopy, 56, 1819-1823. http://dx.doi.org/10.1016/S1386-1425(00)00241-9

[23] Lee, W.K.W. and Van Deventer, J.S.J. (2003) Use of Infrared Spectroscopy to Study Geopolymerization of Heterogeneous Amorphous Aluminosilicate. Langmuir, 19, 8726-8734. http://dx.doi.org/10.1021/la026127e

[24] Rahier, H., Wastiels, J., Biesemans, M., Willem, R., Van Assche, G. and Van Mele, B. (2007) Reaction Mechanism, Kinetics and High Tempera-Ture Transformations of Geopolymers. Journal of Materials Science, 42, 2982-2996. http://dx.doi.org/10.1007/s10853-006-0568-8 